\title{
Mandatory Blood Donor Screening for Human T-Cell Lymphotropic Virus Type I and Type II in Saudi Arabia: Need for Review
}

\author{
H S Mohamud ${ }^{1 *}$, E AIGhamdi ${ }^{1}$, A F Alhetheel ${ }^{2}$, F M AIMajid $^{3}$, A H Ahmed $^{4}$, A M Somily ${ }^{2}$ and D H Mohamed ${ }^{2}$ \\ ${ }^{1}$ Transfusion Microbiology Department, King Khalid University Hospital Blood Bank, Riyadh, Saudi Arabia \\ ${ }^{2}$ Pathology/Microbiology Division, College of Medicine, King Saud University, Riyadh, Saudi Arabia \\ 3 Infectious Diseases Division, College of Medicine, King Saud University, Riyadh, Saudi Arabia \\ ${ }^{4}$ Family and Community Medicine, College of Medicine, King Saud University, Riyadh, Saudi Arabia
}

*Corresponding author: HS Mohamud, Transfusion Microbiology Department, King Khalid University Hospital Blood Bank, Riyadh 11461, Saudi Arabia, Tel: 00966560002637; E-mail: hanet2020@yahoo.co.uk

Rec date: Oct 5, 2016; Acc date: Nov 14, 2016; Pub date: Nov 17, 2016

Copyright: (c) 2016 HS Mohamud, et al. This is an open-access article distributed under the terms of the Creative Commons Attribution License, which permits unrestricted use, distribution, and reproduction in any medium, provided the original author and source are credited.

Abstract
Background
HTLV blood donor screening is recommended practice in high prevalence countries. However, although studies
of HTLV seroprevalence in Saudi Arabia agree these viruses present limited threat in the country, serological
screening of HTLV-I/-II in all prospective blood donor candidates is mandatory practice. Since the last publication
of HTLV seroprevalence in Saudi Arabia 10 years ago, we review 2014-2015 data of 23,668 blood donors attending
King Khalid University Hospital (KKUH) Riyadh, to determine whether this mandatory practice needs review.
Materials and methods
Serology screening was performed on the Abbott Architect system running the rHTLV assay. Repeat reactive
results were confirmed by Western Blot analysis.
Results
This study revealed zero HTLV-I/-II seroprevalence amongst 23,668 donors over the study period.
Discussion
We further support Saudi Arabia as a HTLV non-endemic region, and review more cost-effective strategies to
minimize HTLV risks as an alternative to mandatory blood donor screening.

Keywords: HTLV-I; HTLV-II; Saudi Arabia; Blood donors; Screening

\section{Introduction}

Human T-cell lymphotropic virus type I and type II (HTLV-I and HTLV-II), two closely related human type C retroviruses discovered in the late 1970s to early 1980s are associated with several neurologic disorders [1-3]. HTLV-I is the etiological agent of HTLV-I associated myelopathy (HAM), adult T-cell leukemia (ATL) and tropical spastic paraparesis (TSP) [4-5], whilst HTLV-II has been associated with HAM/TSP-like neurodegenerative diseases [6]. Transmission can occur sexually, parentally, via the sharing of contaminated needles among intravenous drug users (IVDU) and also via the transfusion of contaminated blood. Cases of transfusion transmitted HTLV infections have been documented since the 1980s [7-11]. Consequently, the World Health Organization (WHO) recommends screening blood donors for HTLV-I/II infections in high prevalence countries.

The Kingdom of Saudi Arabia is generally considered a HTLV nonendemic region since the seroprevalence of HTLV-I/II amongst the
Saudi population has been reported to range from $0-0.046 \%$ [12-18]. Nevertheless, serological screening of HTLV-I/II in all prospective blood donor candidates is mandatory practice in Saudi Arabia. We present two years (2014-2015) blood donor serological screening data for HTLV-I/II at a tertiary care hospital in Central Saudi Arabia, to further support this region as non-endemic, and review more costeffective HTLV prevention strategies to current mandatory screening practices.

\section{Materials and Methods}

\section{Study design/subjects studied}

This study comprised a retrospective analysis of HTLV seroprevalence amongst blood donors attending King Khalid University Hospital (KKUH) blood bank, Riyadh Saudi Arabia, between 1st January 2014 and $31^{\text {st }}$ December 2015. 
Citation: E AlGhamdi, A F Alhetheel, F M AlMajid, A H Ahmed, A M Somily, et al. (2016) Mandatory Blood Donor Screening for Human T-Cell Lymphotropic Virus Type I and Type II in Saudi Arabia: Need for Review. J Blood Disord Transfus 7: 371. doi: $10.4172 / 2155-9864.1000371$

Page 2 of 3

\section{Serological screening}

Serology screening was performed using the Architect system (Abbott Diagnostics, Wiesbaden, Germany), running the rHTLV-I/II assay for the qualitative detection of antibodies to HTLV-I and HTLVII in human serum or plasma. Samples with a sample/cutoff ratio ( $\mathrm{S} / \mathrm{CO})$ of $\geq 1.00$ were initially considered reactive and were repeat tested in duplicate using the same assay. If both of the duplicate tests were negative, the donation was considered suitable for release into the clinical inventory. If one or both duplicates were still reactive, confirmatory testing was performed using a commercial Western Blot assay (Genelabs Diagnostics, Geneva, Switzerland) according to the manufacturer's instructions. A sample was considered HTLV-I seropositive if reactive to GAG (p19 with or without p24) and 2 ENV (GD21 and rgp 46-I) proteins and HTLV-II seropositive if reactive to GAG (p24 with or without p19) and 2 ENV (GD21 and rgp 46-II).

\section{Results}

During the study period, a total of 23,668 donors were screened for anti-HTLV-I/-II antibodies. The majority of donors screened were male $(93.5 \%)$, volunteer donors $(56.9 \%)$, of Saudi nationality $(78.2 \%)$ (Table 1). Initial screening on the Architect system yielded 14 repeat reactive donations (Table 2). Confirmatory testing by Western Blot analysis revealed 14 negative results and 1 indeterminate result.

\begin{tabular}{|l|l|}
\hline Characteristic & Total number (\%) \\
\hline Male & $22130(93.5)$ \\
\hline Female & $1538(6.5)$ \\
\hline Saudi & $18508(78.2)$ \\
\hline Non-Saudi & $5160(21.8)$ \\
\hline Volunteer & $13467(56.9)$ \\
\hline Replacement & $10201(43.1)$ \\
\hline
\end{tabular}

Table 1: Demographics of blood donors attending KKUH blood bank between 2014 and 2015.

\begin{tabular}{|l|l|l|lr|}
\hline Year & $\begin{array}{l}\text { Number of blood units } \\
\text { screened }\end{array}$ & $\begin{array}{l}\text { Repeat } \\
\text { seroreactive }\end{array}$ & $\begin{array}{l}\text { Western } \\
\text { analysis }\end{array}$ & Blot \\
\hline 2014 & 12,496 & $8(0.06)$ & 8 negative & \\
\hline 2015 & 11,172 & $6(0.005)$ & $\begin{array}{l}5 \text { negative, } \\
\text { indeterminate }\end{array}$ & 1 \\
\hline Total & 23,668 & $14(0.065)$ & 14 \\
\hline
\end{tabular}

Table 2: HTLV -I/-II seroprevalence amongst blood donors attending KKUH between 2014 and 2015.

\section{Discussion}

HTLV-I has a global distribution with highest prevalence rates in Japan, the Caribbean and in parts of South America and Africa $[4,19]$. However, HTLV-II has endemic foci in the Indian subcontinent, and North/South America [20,21]. To date, all reports of HTLV-I/II seroprevalence in Saudi Arabia have been very low. Murphy [22] estimates Saudi Arabia's HTVL-I/II seroprevalence as 0.000028 based on 7 studies reporting HTLV screening results between 1997 and 2005.
In non-endemic areas, HTLV risks are primarily associated with travel or residence history in endemic countries. Other high risk factors include country of birth, parental ethnicity, sexual contact with individuals from HTLV endemic areas and/or at-risk household contacts [23]. The Saudi Arabian workforce currently comprises a significant proportion of expatriate workers originating from HTLV endemic regions, e.g. the Indian subcontinent. This may have been the initial justification for implementation of the mandatory screening of HTLV-I/-II in blood donors in Saudi Arabia. However, blood donor screening policies should be primarily based on local epidemiological evidence, which in this case do not indicate a significant HTLV threat.

Our study revealed zero HTLV seroprevalence amongst 23,668 blood donor attending KKUH Riyadh between 2014 and 2015. This is in agreement with a previous study performed in the same hospital investigating HTLV infection in 24,173 blood donors over a 3 year period (January 2000-December 2002) which also reported zero HTLV infections [14]. Both studies highlight the limited threat of HTLV-I/-II infections to the safety of the blood supply in this region. Additionally, other studies investigating blood donor screening outcomes in Saudi Arabia have also shown that the majority of voluntary donors are from the native Saudi population and report a very low seroprevalence, supporting the country as a non-endemic region for HTLV infections [12-18]. We therefore question the cost-effectiveness of continued universal HTLV-I/-II screening of all blood donors in a low-prevalence country.

An alternative HTLV screening strategy proposed by Arif and Ramia [13] was to screen only the expatriate blood donor population. Kawashti et al. [17] also proposed HTLV screening of pooled sera instead of individual serum screening. However, a more pragmatic and still cost-effective strategy would be to implement stringent donor selection guidelines to identify donors with possible risk factors for HTLV and to selectively screen only at-risk donors, whilst deferring individuals with particularly high-risks of HTLV infection. Additionally, educating prospective donors on risk exposure for HTLV would encourage more open disclosure of infective risk factors, and encourage self-deferral of high risk donors. Such prevention strategies would be applicable to all transfusion transmissible infections, not just HTLV.

\section{Conclusions}

In conclusion, based on the collective reported frequencies of HTLV infections in Saudi Arabia, the current mandatory screening of all blood donors is neither justified nor cost-effective. We encourage the policy makers in the Saudi Ministry of Health to shift focus of HTLV prevention strategies to implementing selective screening of only atrisk blood donors and expanding donor education campaigns.

\section{Acknowledgments}

The authors thank the following KKUH Transfusion Microbiology Blood Bank staff for their contributions to this work: Mr. Abdulaziz AlQarni, Mr. Abdullah Al-Ghamdi and Mrs. Dhuha Bedawi.

\section{Funding and Resources}

This project was supported by the College of Medicine Research Chair, Deanship of Scientific Research, King Saud University, Riyadh, Saudi Arabia. 
Citation: E AlGhamdi, A F Alhetheel, F M AlMajid, A H Ahmed, A M Somily, et al. (2016) Mandatory Blood Donor Screening for Human T-Cell Lymphotropic Virus Type I and Type II in Saudi Arabia: Need for Review. J Blood Disord Transfus 7: 371. doi: $10.4172 / 2155-9864.1000371$

Page 3 of 3

\section{Author contributions}

HM and EA designed the study, HM and AFA collected the data, HM, AFA, AS, FMA, AHA and DM performed the analysis, interpretation and wrote the manuscript.

\section{Disclosure of conflicts of interests}

None to declare.

\section{References}

1. Poiesz BJ, Ruscetti FW, Gazdar AF, et al.(1980) Detection and isolation of type $\mathrm{C}$ retrovirus particles from fresh and cultured lymphocytes of a patient with cutaneous T-cell lymphoma. Proc Natl Acad Sci U S A 77: 7415-7419.

2. Poiesz BJ, Ruscetti FW, Reitz MS, et al.(1981) Isolation of a new type C retrovirus (HTLV) in primary uncultured cells of a patient with Sézary Tcell leukaemia. Nature 294: 268-271.

3. Kalyanaraman VS, Sarngadharan MG, Robert-Guroff M, et al.( 1982) A new subtype of human T-cell leukemia virus (HTLV-II) associated with a T-cell variant of hairy cell leukemia. Science 218: 571-573.

4. Gessain A, Cassar O.( 2012) Epidemiological aspects and world distribution of HTLV-1 infection. Front Microbiol 3: 388

5. Rafatpanah H, Hedayati-Moghaddam MR, Fathimoghadam F, et al. ( 2011) High prevalence of HTLV-I infection in Mashhad, Northeast Iran: A population-based seroepidemiology survey. J Clin Virol 52: 172-176.

6. Araujo A, Hall WW.(2004) Human T-lymphotropic virus type II and neurological disease. Ann Neurol 56: 10-19.

7. Okochi K, Sato H, Hinuma Y.( 1984) A retrospective study on transmission of adult $\mathrm{T}$ cell leukemia virus by blood transfusion: seroconversion in recipients. Vox Sanguinis 46: 245-253.

8. Manns A, Wilks RJ, Murphy EL, et al.(1992) A prospective study of transmission by transfusion of HTLV-I and risk factors associated with seroconversion. Int J Cancer51: 886-891.

9. Donegan E, Busch MP, Galleshaw JA, et al.( 1990) Transfusion of blood components from a donor with human T-lymphotropic virus type II (HTLV-II) infection. The Transfusion Safety Study Group. Ann Intern Med 113:555-556

10. Kleinman S, Swanson P, Allain JP, et al.(1993) Transfusion transmission of human T-lymphotropic virus types I and II: serologic and polymerase chain reaction results in recipients identified through look-back investigations. Transfusion 33: 14-18.
11. O'Brien SF, Goldman M, Scalia V, et al.( 2013) The epidemiology of human T-cell lymphotropic virus types I and II in Canadian blood donors. Transfus Med 23: 358-366.

12. Bernvil SS, Andrews V and Coulter N.( 1997) International forum: Saudi Arabia. Donor screening for HTLV-I in Saudi Arabia: is it cost effective? Transfus Sci 18: 45-47.

13. Arif M, Ramia S.( 1998) Seroprevalence of human virus type I HTLV I in T lymphotropic Saudi Arabia. Annals of Tropical Medicine and Parasitology 92: 305-309.

14. El-Hazmi MM.( 2004) Prevalence of HBV, HCV, HIV-1, 2 and HTLV-I/II infections among blood donors in a teaching hospital in the Central region of Saudi Arabia. Saudi Med J 25: 26-33.

15. Balkhy HH, Memish ZA, Abed E, et al.( 2004) Saudi National Guard donor screening for human $\mathrm{T}$ cell lymphotropic virus I/II: time to use molecular biology techniques. Mil Med 169: 251-253.

16. Ul-Hassan Z, Al-Bahrani AT, Panhotra BR.( 2004) Prevalence of human T-lymphotropic virus type I and type II antibody among blood donors in Eastern Saudi Arabia. Saudi Med J 25: 1419-1422.

17. Kawashti MI, Hindawi SI, Damanhouri GA, et al.( 2005) Serological screening of human T cell lymphotropic virus I and II (HTLV-I/-II) in blood banks by immunoblotting and enzyme-immuno assays: to demand or to defeat? Egypt J Immunol 12:137-142.

18. Fawaz NA, Tamim H, Almawi WY.( 2005) Low prevalence of antibodies to human T-lymphotropic virus-I/II among blood donors in eastern Saudi Arabia. Am J Infect Control 33:189-191.

19. Proiette FA, Carneiro-Proietti AB, Catalan-Soares BC, et al.( 2005) Global epidemiology of HTLV-I infection and associated diseases. Oncogene 24: 6058-6068.

20. Vrielink H, Reesink HW.( 2004) HTLV-I/II prevalence in different geographic locations. Transfus Med Rev 18: 46-57.

21. Hall WW, Ishak R, Zhu SW, et al.( 1996) Human T lymphotropic virus type II (HTLV-II): epidemiology, molecular properties, and clinical features of infection. J Acquir Immune Defic Syndr Hum Retrovirol 13: S204-S214.

22. Murphy EL.( 2016) Infection with human T-lymphotropic virus types-1 and -2 (HTLV-1 and -2): Implications for blood transfusion safety. Transfusion Clinique et Biologique; 23: 13-19.

23. Hedayati-Moghaddam MR, Tehranian F, Bayati M.( 2015) Human TLymphotropic Virus Type I (HTLV-1) Infection among Iranian Blood Donors: First Case-Control Study on the Risk Factors. Viruses 7: 5736-5745. 